\title{
DEVELOPING A MATHEMATICS LEARNING MEDIA TO EXPLAIN FORMULA OF AREA OF KITE USING HAWGENT
}

\author{
Jerito Pereira $^{1^{*}}$, Shiwei $\mathrm{Tan}^{2}, \mathrm{Li} \mathrm{Li}^{3}$, Aditya Purnama ${ }^{4}$ \\ ${ }_{1,2,3,4}$ Department Mathematics and Statistics, Guangxi Normal University, China \\ *Corresponding author: jeritopereira@gmail.com
}

\begin{tabular}{|c|c|c|}
\hline \multicolumn{3}{|c|}{ Article Info } \\
\hline \multicolumn{3}{|c|}{ Article history: } \\
\hline $\begin{array}{l}\text { Received: } \\
2020\end{array}$ & November & 01, \\
\hline $\begin{array}{l}\text { Accepted: } \\
2020\end{array}$ & November & 25 , \\
\hline $\begin{array}{l}\text { Published: } \\
2020\end{array}$ & November & 30 , \\
\hline
\end{tabular}

Keywords:

Class IV

Elementary school

Hawgent dynamic mathematics

Kite area

Learning media

Software

\begin{abstract}
This study aims to develop Hawgent Dynamic Mathematics Software Learning Media. The broad material of ICT-based kites as a medium for learning mathematics for grade IV SD students. The research method used in this research is Research and Development (R\&D) with a 4-D model. The results of the material expert's assessment of the six components include: the language aspect is $70 \%$, the ease of use of learning media reaches the highest average of $90 \%$, and it is concluded that the overall average percentage is $83.33 \%$. It can be said that the ICT-based learning media that have been designed are in the feasible category. While the results of the material expert's assessment of the four aspects obtained an average percentage of $87.89 \%$. Based on the results of the study Hawgent Dynamic Mathematics Software Learning Media can be used as a learning media for learning mathematics to find the area of a kite.
\end{abstract}

\section{PENGEMBANGAN MEDIA PEMBELAJARAN MATEMATIKA UNTUK MENJELASKAN FORMULA LUAS AREA LAYANG- LAYANG MENGGUNAKAN HAWGENT}

\section{Kata Kunci:}

Kelas IV

Sekolah dasar

Hawgent dynamic mathematics

Luas area layang-layang

Media pembelajaran

Software \begin{abstract}
ABSTRAK
Penelitian ini bertujuan untuk mengembangkan Media Pembelajaran berbasis Software Matematika Dinamis Hawgent. Materi yang digunakan dalam penelitian ini adalah tentang layanglayang berbasis TIK sebagai media pembelajaran matematika bagi siswa kelas IV SD. Metode penelitian yang digunakan dalam penelitian ini adalah Research and Development (R\&D) dengan model 4-D. Hasil penilaian ahli materi terhadap keenam komponen tersebut mencakup: aspek bahasa adalah 70\%, kemudahan penggunaan media pembelajaran mencapai rata-rata tertinggi sebesar $90 \%$, dan disimpulkan persentase rata-rata keseluruhan sebesar 83,33\%. Dapat dikatakan bahwa media pembelajaran berbasis TIK yang telah dirancang termasuk dalam kategori layak. Sedangkan hasil penilaian ahli materi dari keempat aspek tersebut diperoleh persentase rata-rata sebesar 87,89\%. Berdasarkan hasil penelitian, Software Pembelajaran Matematika Dinamis Hawgent dapat digunakan sebagai media pembelajaran matematika untuk mencari luas suatu layang-layang.
\end{abstract}




\section{INTRODUCTION}

In the current era of globalization, education is one of the main factors that greatly affects and develops the skills of the human being [1], [2], so that some experts interpret education as a process of changing the attitudes and behaviour of a person or group of people in maturing through teaching, training and so on [3], [4]. Therefore, education is very helpful for children to increase knowledge, physical and moral, which gradually and can lead children to the highest goal to benefit themselves and society. Because the importance of these factors, so that we are very required to improve and ensure the quality of education in primary schools in particular because primary school education is the initial process in shaping student character [5]. Thus, this demand is none other than a challenge for education today how to find and creating effective learning media to facilitate teachers and also make it easier for students to understand the concept of a particular lesson [6], [7].

Teaching and learning activity is the teacher's effort to direct and guide the student learning process with learning media to achieve the expected learning objectives [8]. Teachers are required to be able to use appropriate methods, or by developing teaching materials that are more interesting and easy for students to understand [9]-[11]. This is so that students can receive the learning process well, besides that this is expected to increase students' interest in various kinds of teaching materials [12], [13]. One of them is mathematics which is very difficult to learn and understand by students at school [14][17].

Based on the results of previous researches, most mathematics teachers said that the learning methods used so far were still using conventional methods, namely the lecture and question and answer methods [18]-[20]. Learning using this method has not encouraged students to learn independently, it is difficult to understand concepts because students only take notes and listen to the explanations given by the teacher, and are lazy to seek knowledge outside the teacher's explanations, so the achievement of student learning outcomes is very low and less satisfying or not optimal. This shows that the students' mathematics learning outcomes are still low so that they have not achieved mastery learning [21]. So, it is expected that a media based on information and communication technology.

The material for the area of a 2-dimensional figure, in this case, the area of the kite, is a rectangular or two-dimensional shape formed by two pairs of ribs, each of which has the same length and forms an angle [22]. Likewise, it has specific properties. Namely, the sides are a pair of the same length, a pair of opposite angles are equal in length, one diagonal bisects the length of the other diagonal, so the two diagonals are perpendicular to each other. Thus, the use of this new learning media can help students understand the kite concept and prove the area formula with computer-based media to achieve the expected learning media plans and objectives.

Technology-based learning has a significant role in solving learning problems, which is emphasized by NCTM [23]; technology is essential in learning and teaching mathematics. Technology affects the mathematics taught and improves student learning [5], [24]. One solution is to create innovative learning media that is tailored to the characteristics of the material and the conditions and strategies used by the educators. that researcher used hawgent dynamic mathematics software learning media because it has a better menu view, graph and very easy to use with features and interesting animation.

Research on improving students' mathematical abilities on two-dimensional figure material is widely used, but not many studies have developed technology-based learning media who have good animation. Based on the description above, it can be concluded that 
the mathematical material chosen by the author in the development of the Hawgent Dynamic Mathematics Software Learning media is the area of the kite area for grade VI elementary school students. This study aims to describe the process and results of developing a useful and practical Hawgent Dynamic Mathematics Software learning model on the area of the kite area for grade VI elementary school students.

\section{METHOD}

This research is a type of Research and Development (R\&D) [25], [26]. According to the literature, research and development method is a research method used to produce specific products and test the effectiveness of these products. This research design uses a 4-D (define, design, develop, and disseminate) model, with the concept of thought can be seen as follows [27].

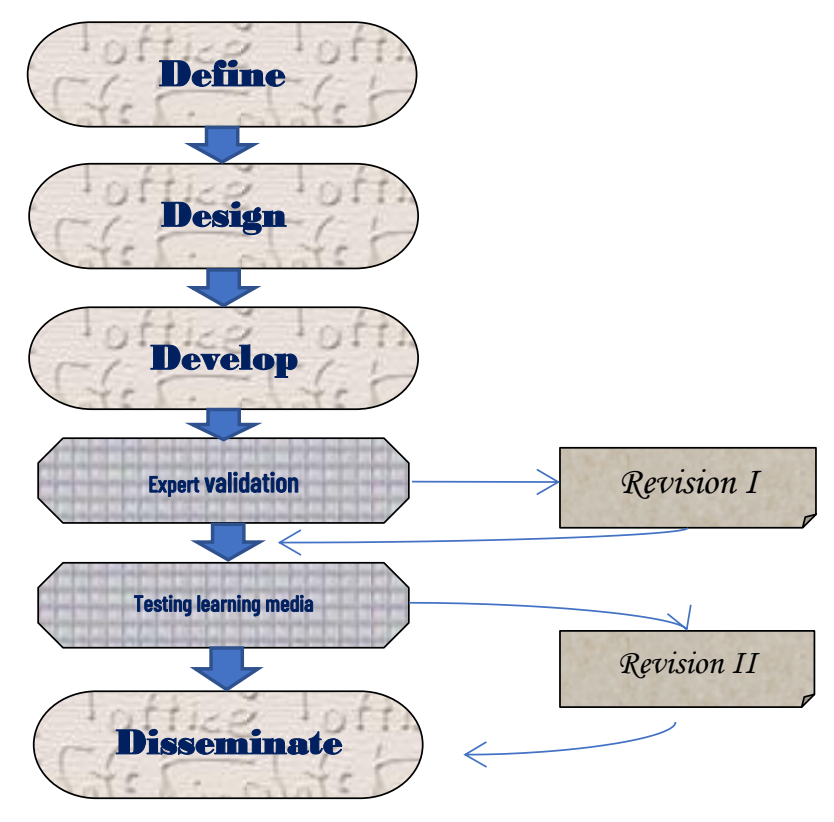

Figure 1. The Flow of a 4-D Research and Development Model

\subsection{Define}

At the define stage, the researcher carries out several main activities, including; front-end analysis and specifying instructional objectives.

\subsubsection{Front-End Analysis}

This Front-End Analysis aims to describe the main factors that significantly influence daily life which are challenges and future demands. Through the initial diagnosis, facts, hopes and finding alternative solutions to problems regarding the development of learning media are obtained, and if learning is carried out with technology-based learning media, it will increase the competence of each student in meeting future demands.

\subsubsection{Specifying instructional objectives}

The formulation of learning objectives is the expected behaviour change after learning to summarize the results of concept analysis to determine the behaviour of the object of research. This collection of objects is the basis for designing learning media. 


\subsection{Design}

In this stage, the researcher designs the learning media or product design and selects the subjects to be studied using the learning model and the learning objectives. Therefore, the researcher designs technology-based learning media using Hawgent Dynamic Mathematics Software in a kite-wide mathematics lesson. for grade VI SD students.
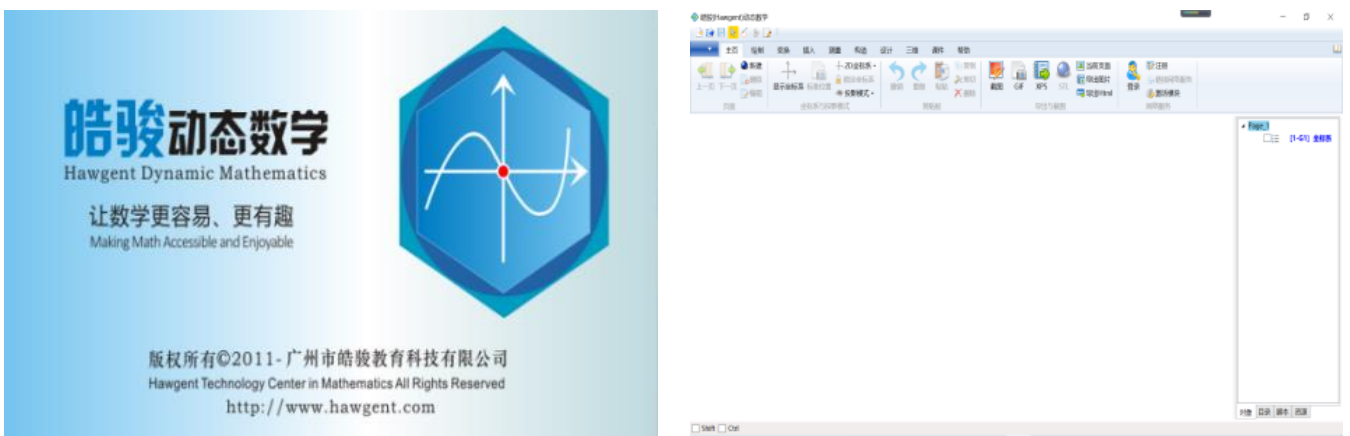

Figure 2. The Pictures of Learning Media Hawgent Dynamic Mathematics Software

\subsection{Develop}

There are two activities that carried out in this development stage, including:

\subsubsection{Expert validation}

The validation stage of the model or ICT-based learning media by experts. The assessment components that are validated includes aspects and categories of the use of learning media. The team of experts involved in the validation process consists of instructional media display experts and subject matter experts.

\subsubsection{Testing learning media on a small group}

The legibility test was carried out on several colleagues, seniors and selected lecturers to see whether the learning in the form of information and communication technology could be read clearly and easily understood.

\subsection{Disseminate}

In the validation test stage, the product that has been revised at the development stage is then implemented on its real target. During implementation, the measurement of the achievement of the objectives is carried out to determine the effectiveness of the product being developed. After the product is implemented, the developer needs to see the results of achieving the goals. The unattainable goal needs to be explained the solution so that the same mistakes do not repeat after the product is disseminated.

\section{RESULTS AND DISCUSSION}

\subsection{Define}

At this defining stage, there are two stages of analysis described by the researcher, among others:

\subsubsection{Front-End Analysis}

At this stage, the researcher carried out observations to know the basic problems that exist and for further finding a solution. Front end analysis was carried out by interviewing the sixth-grade mathematics teacher. Thus, the problems that occur include the learning that has been carried out by the teacher does not involve student activity. The teacher still 
uses the traditional method, for example explaining concepts or procedures with a few questions and answers, giving examples of questions and providing practice questions. This results in students not accustomed to constructing knowledge or how to solve them on their own. Therefore, the teacher expects the use of this ICT - based learning media to:

1. Learning is not centred on the teacher but students.

2. Students quickly understand mathematics subject material because it is associated with real-world situations (contextual).

3. Students can apply the material they learn, both to solve problems and problems in daily life.

4. Can improve student mathematical abilities.

Furthermore, the researcher made observations of grade VI students with the results of the observations as follows:

1. I tend only to accept explanations and take notes on the material provided by the teacher.

2. I feel passive in the learning process because I do not get the opportunity to develop my skills and abilities.

3. The model used in mathematics learning is less attractive to me because it uses a conventional learning model where we only listen to the teacher's explanation and are not actively involved in the learning process.

\subsubsection{Specifying instructional objectives}

The learning objectives are formulated following the basic competencies in the material of the area of the kite, namely 1) Students can understand that a kite is a rectangle with two pairs of adjacent sides of the same length. 2) The kite has two diagonals which intersect perpendicularly. 3) An ABCD kite is cut according to its diagonal. The pieces are then arranged into a rectangle. Thus, the area of the kite is equal to the area of the rectangle. The length of the rectangle is the same as the diagonal length of 1 (d1). At the same time, the width is equal to half the length of the diagonal.

\subsection{Design}

\subsubsection{Selection learning media}

This media selection is carried out to identify the right media that is by the characteristics of the learning material. Therefore, in this study, the material developed in the Hawgent Dynamic Mathematics Software Learning Media. The media used in learning include image media, along with interesting animations that are available in the device. This media is expected to help students in understanding the material area of the kite area and find the concepts on it. With this media selection, it is hoped that students will enjoy mathematics more and be more enthusiastic and active in learning. For more details, it can be seen at the following stages.

Table 1. Media Learning Storyboard

\begin{tabular}{|c|c|c|c|}
\hline No & Visual Stages & & Explanation \\
\hline \multirow[t]{2}{*}{1} & 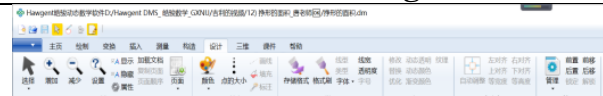 & 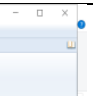 & $\begin{array}{l}\text { at the first stage, shows the results of proving } \\
\text { the area formula for the kite area using }\end{array}$ \\
\hline & •. & 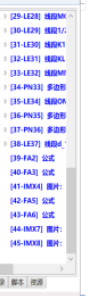 & $\begin{array}{l}\text { explains the advantages of the software such } \\
\text { as menu display, animation and so on. And } \\
\text { then open a new page to start is seen at the } \\
\text { following stage. }\end{array}$ \\
\hline
\end{tabular}

276 Indonesian Journal of Science and Mathematics Education 
2

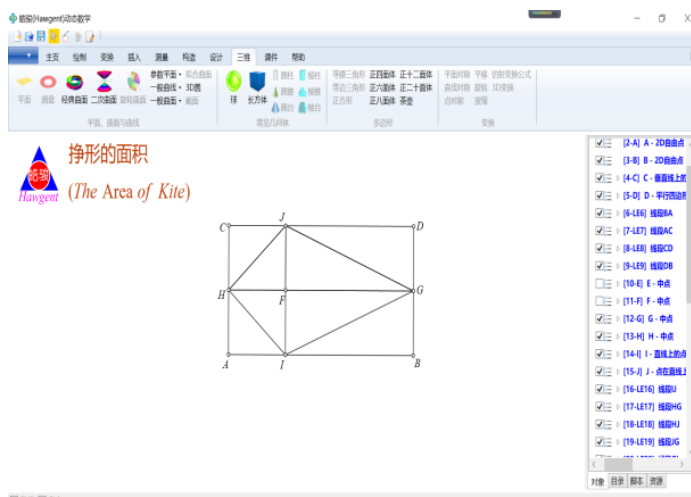

3
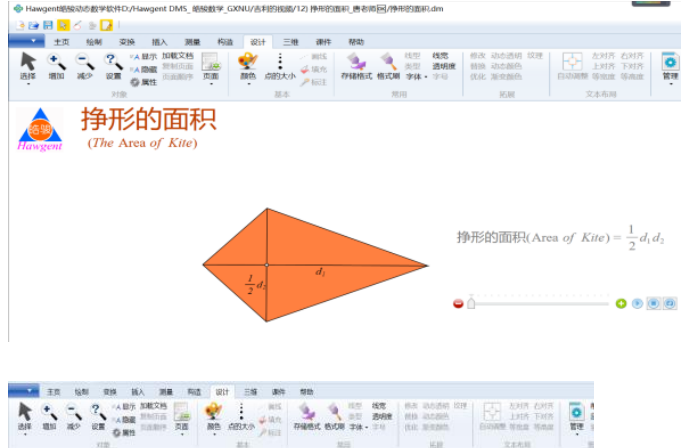
挣形的面积
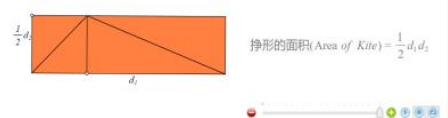

4

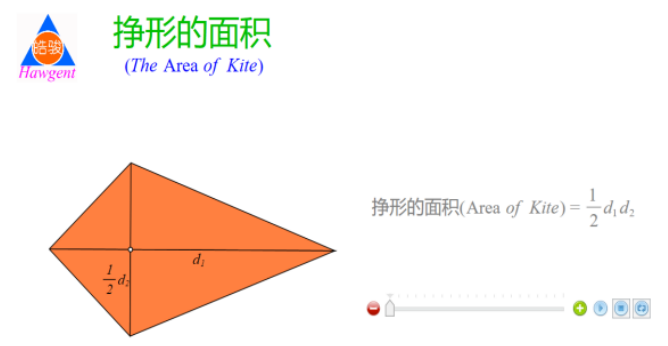

Create a rectangle and midpoint between the lines $\mathrm{AC}$ and $\mathrm{BD}$, and make a point on the lines $\mathrm{AB}$ and $\mathrm{CD}$. Next connect each point of HIGJ, IJ and GH, and create an intersection point at the centre where the IJ and GH lines meet. Then in the rectangle is formed a kite. Next, delete the rectangle which can be seen in the following step;

This stage, giving colour to each area of the kite and making a button that will help to make diagonal cuts. we observe that a kite will be cut according to its diagonal. The pieces are then arranged into a rectangle. Thus, the area of the kite is equal to the area of a rectangle with two diagonals as shown in the following image.

Conclusion, in the last stage, proved that The length of the rectangle is the same as the diagonal length of $1(\mathrm{~d} 1)$. While the width is equal to half the length of the diagonal 2 (d2). Therefore, in those stages above it is evident that:

Area of the Kite

$=$ Area of the Rectangle

$=\mathrm{p} \times 1$

$=\mathrm{d}_{1} \times \frac{1}{2} \mathrm{~d}_{2}$

$=\frac{1}{2} d_{1} \times d_{2}$

\subsection{Develop}

\subsubsection{Media expert validation data}

The results of validation by media experts in the development of Learning Media for Hawgent Dynamic Mathematics Software in Class VI Elementary Schools can be seen in the following table. 
Table 2. The Results of The Media Expert's Validation

\begin{tabular}{clccc}
\hline No & \multicolumn{1}{c}{ Assessment Component } & Validation Score & Percentage & Category \\
\hline 1 & $\begin{array}{l}\text { Appropriateness of language used learning } \\
\text { media planning measures } \\
2\end{array}$ & 2.1 & 70 & $\begin{array}{c}\text { Feasible } \\
\text { enough } \\
\text { fhe design view that is presented clarifies } \\
\text { the design stages. }\end{array}$ \\
$\begin{array}{l}\text { Animations and simulations used in the } \\
\text { media make it easier to understand the } \\
\text { material }\end{array}$ & 2.6 & 86.67 & feasible \\
4 & $\begin{array}{l}\text { Display of letters and neatness of writing } \\
\text { layout used in learning media } \\
\text { The sound quality in this electronic module } \\
\text { is good } \\
\text { The software is easy to use }\end{array}$ & 2.4 & 86.67 & feasible \\
$\quad$ Average (\%) & 82.67 & feasible \\
\hline
\end{tabular}

Based on Table 2, the results of the material expert's assessment of the six components obtained different percentages from one component to another component, the component of the suitability of the language used is in the lowest category, or it is just quite feasible because there is no English or other language, so it needs to be revised again. However, it is easy for the learning media to reach the highest average of $90 \%$, and it is concluded that the overall average percentage is $83.33 \%$. It can be said that the ICT - based learning media that have been designed are in the feasible category and need to be revised a little to meet the maximum learning media standards to be used on other topics.

\subsubsection{Material expert validation data}

The results of validation by material experts in the development of Hawgent Dynamic Mathematics Software Learning Media in Class VI Elementary Schools can be seen in Table 3.

Table 3. Validation Results from The Validator

\begin{tabular}{clccc}
\hline No & \multicolumn{1}{c}{ Assessment Components } & Score of Validation & Percentage & Category \\
\hline 1 & $\begin{array}{l}\text { The concept of lines in the design of Learning } \\
\text { Media }\end{array}$ & 2.5 & 86.67 & Feasible \\
2 & $\begin{array}{l}\text { The diagonal concept of 2-dimensional } \\
\text { figures in the design of Learning Media } \\
\text { Media Hawgent Dynamic Mathematics }\end{array}$ & 2.5 & Feasible \\
$\begin{array}{l}\text { Software } \\
\text { The suitability of the presentation of the } \\
\text { material with the level of development of } \\
\text { students' knowledge } \\
\text { The concept of the area of the kite area in the }\end{array}$ & 2.4 & 85.33 & Feasible \\
Hawgent & 2.7 & 87.56 & Feasible \\
\hline \multicolumn{1}{c}{ Average of learning media (\%) } & 87.89 & Feasible \\
\hline
\end{tabular}

Based on Table 3, the results of the material expert's assessment of the four aspects obtained an average percentage of $87.89 \%$. This can be said that the ICT - based learning media that have been designed are in the feasible category and need to be revised a little to meet the maximum learning media standards to be able to use on other subjects.

\subsection{Disseminate}

Based on the results of the validation of media experts and material experts and with revised results from several aspects, the results of product design or technology-based learning media, communication and information will be disseminated, promotion and 
developed to prove the formula for the area of other 2 dimensional figures and can also be used. In other primary schools for mathematics in particular. In this last stage, the researcher realized the socialization of Hawgent dynamic mathematics software media learning to other mathematics teachers of different levels and schools. in the future, the teacher can use technology on other topics or other levels especially mathematics lesson.

A lot of study has been done on developing instructional media to find kite areas [28], [29]. Such as research conducted by Lestari [30], teaching kite material using didactical design. But there has not been any development of learning media that uses technology in the material to find the area of a kite. It is hoped that this research can improve the development of technology-based learning media. For further research, elementary school materials can be developed using hawgent dynamic mathematics software or another dynamic mathematics software to increase students' interest in learning and make students more active in teaching and learning activities.

\section{CONCLUSION}

Based on the results of the material expert's assessment of the six components in the media aspect and the four components in the material aspect, the overall average category feasible respectively. It can be said that the ICT - based learning media, namely, the Hawgent Dynamic Mathematics Software Learning Media, can be used to prove the formula for the area of the kite area in mathematics in Class VI elementary schools. In further research, elementary school materials can be developed using hawgent dynamic mathematics software or another dynamic mathematics software to increase students' interest in learning and make students more active in teaching and learning activities. For further research, elementary school materials can be developed using hawgent dynamic mathematics software or another dynamic mathematics software to increase students' interest in learning and make students more active in teaching and learning activities.

\section{REFERENCES}

[1] S. I. Kulsum, W. Hidayat, T. T. Wijaya, and J. Kumala, "Analysis on high school students' mathematical creative thinking skills on the topic of sets," J. Cendekia $J$. Pendidik. Mat., vol. 03, no. 02, pp. 431-436, 2019.

[2] W. Aixia, Z. Ying, and T. T. Wijaya, "The current situation and prospect of study quality evaluation research in china in the last 10 years," EDUKATIF J. ILMU Pendidik., vol. 2, no. 1, pp. 101-112, 2020.

[3] S. N. Dewi, T. T. Wijaya, A. Budianti, and E. E. Rohaeti, "Pengaruh Model Teams Games Tournament Terhadap Kemampuan Pemahaman Matematik Siswa Kelas XI SMK di Kota Cimahi Pada Materi Fungsi Eksponen," WACANA Akad. Maj. Ilm. Kependidikan, vol. 2, no. 1, p. 99, 2018.

[4] M. Dini, T. T. Wijaya, and A. I. Sugandi, "Pengaruh Self Confidence Terhadap Kemampuan Pemahaman Matematik Siswa Smp," J. Silogisme, vol. 3, no. 1, pp. 17, 2018.

[5] M. Bernard and S. Chotimah, "Improve student mathematical reasoning ability with open-ended approach using VBA for powerpoint," AIP Conf. Proc., vol. 2014, no. September, 2018.

[6] T. T. Wijaya, S. Murni, A. Purnama, and H. Tanuwijaya, "Pengembangan media pembelajaran berbasis tpack menggunakan hawgent dynamic mathematics software," COLLASE (Creative Learn. Students Elem. Educ., vol. 3, no. 3, pp. 64$72,2020$.

[7] M. Hutajulu, T. T. Wijaya, and W. Hidayat, "the Effect of Mathematical Disposition Indonesian Journal of Science and Mathematics Education (IJSME)| 
and Learning Motivation on Problem Solving: an Analysis," Infin. J., vol. 8, no. 2, p. 229, 2019.

[8] L. Cunhua, Z. Ying, O. Qunzhuang, and T. T. Wijaya, "Mathematics course design based on six questions cognitive theory using hawgent dynamic mathematic," $J$. Educ., vol. 02, no. 01, pp. 36-44, 2019.

[9] N. Badraeni et al., "Analisis kesulitan siswa berdasarkan kemampuan pemahaman matematik dalam mengerjakan soal pada materi bangun ruang sisi datar," $J$. Cendekia J. Pendidik. Mat., vol. 04, no. 01, pp. 247-253, 2020.

[10] T. T. Wijaya, N. S. S. Dewi, I. R. Fauziah, and M. Afrilianto, "Analisis Kemampuan Pemahaman Matematis Siswa Kelas IX Pada Materi Bangun Ruang," UNION J. Ilm. Pendidik. Mat., vol. 6, no. 1, pp. 19-28, 2018.

[11] T. T. Wijaya, Z. Ying, and A. Purnama, "Using Hawgent dynamic mathematics software in teaching trigonometry," Int. J. Emerg. Technol. Learn., vol. 15, no. 10, 2020.

[12] T. T. Wijaya, Z. Ying, and A. Purnama, "The empirical research of hawgent dynamic mathematics technology integrated into teaching," J. Cendekia J. Pendidik. Mat., vol. 04, no. 01, pp. 144-150, 2020.

[13] L. Zhang, Y. Zhou, and T. T. Wijaya, "Hawgent dynamic mathematics software to improve problem-solving ability in teaching triangles," J. Phys. Conf. Ser., vol. 1663, no. 1, 2020.

[14] T. T. Wijaya, J. Tang, and A. Purnama, Developing an interactive mathematical learning media based on the tpack framework using the hawgent dynamic mathematics software, vol. 332 LNICST. 2020.

[15] D. P. Dewi, D. Mediyani, W. Hidayat, E. E. Rohaeti, and T. T. Wijaya, "Analisis Kemampuan Berpikir Kritis Matematis Siswa Smp Pada Materi Lingkaran Dan Bangun Ruang Sisi Datar," JPMI (Jurnal Pembelajaran Mat. Inov., vol. 2, no. 6, p. 371, 2019.

[16] D. S. Sari, K. Kusnandi, and S. Suhendra, "A Cognitive Analysis of Students' Mathematical Communication Ability on Geometry," J. Phys. Conf. Ser., vol. 895, no. 1, 2017.

[17] X. Zhang, Y. Zhou, and T. T. Wijaya, "Hawgent Dynamic Mathematics Software to Teach Line and Angle," JNPM (Jurnal Nas. Pendidik. Mat., vol. 4, no. 2, pp. 237-247, 2020.

[18] S. Chotimah, M. Bernard, and S. M. Wulandari, "Contextual approach using VBA learning media to improve students' mathematical displacement and disposition ability," J. Phys. Conf. Ser., vol. 948, no. 1, 2018.

[19] M. Bernard, P. Akbar, A. Ansori, and G. Filiestianto, "Improve the ability of understanding mathematics and confidence of elementary school students with a contextual approach using VBA learning media for Microsoft Excel," J. Phys. Conf. Ser., vol. 1318, no. 1, 2019.

[20] M. Tamur and D. Juandi, "Effectiveness of Constructivism Based Learning Models Against Students Mathematical Creative Thinking Abilities in Indonesia; A MetaAnalysis Study," in Proceedings of the 7th Mathematics, Science, and Computer Science Education International Seminar, MSCEIS 2019, 2020.

[21] T. T. Wijaya, Z. Ying, S. Chotimah, M. Bernard, Zulfah, and Astuti, "Hawgent dynamic mathematic software as mathematics learning media for teaching quadratic functions," in Journal of Physics: Conference Series, 2020, vol. 1592, no. 1.

[22] M. Ikhsan and D. Juandi, “Analisis Penguasaan Siswa Sekolah Menengah Atas pada Materi Geometri," Didakt. Mat., vol. 2, no. 1, pp. 64-70, 2015. 
[23] C. L. Chen and C. C. Wu, "Students' behavioral intention to use and achievements in ICT-Integrated mathematics remedial instruction: Case study of a calculus course," Comput. Educ., 2020.

[24] S. Tan, L. Zou, T. T. Wijaya, N. Suci, and S. Dewi, "Improving student creative thinking ability with problem based learning approach using hawgent," J. Educ., vol. 02, no. 04, pp. 303-312, 2020.

[25] N. Hermita, H. S. Ningsih, J. A. Alim, M. Alpusari, Z. H. Putra, and T. T. Wijaya, "Developing Science Comics for Elementary School Students on Animal Diversity," Solid State Technol., vol. 63, no. 1s, 2020.

[26] T. T. Wijaya, M. Sukma, A. Purnama, and H. Tanuwijaya, "Pengembangan media pembelajaran berbasis tpack menggunakan hawgent dynamic mathematics software," J. Elem. Educ., vol. 03, no. 03, pp. 64-72, 2020.

[27] D. Alvionita, W. Subchan, and M. Iqbal, "The development of ecosystem education game based on Baluran National Park for senior high school," J. Phys. Conf. Ser., vol. 1465 , no. $1,2020$.

[28] J. Almanfaluthi, Betha, "Konsep Motion Graphics Pengenalan LayangLayangSebagai Budaya Bangsa," vol. 7, no. 2, pp. 99-109, 2020.

[29] N. L. Fitri and R. C. I. Prahmana, "Pembelajaran Luas Segiempat untuk Siswa Kelas VII Menggunakan Reallotment Activities," J. Rev. Pembelajaran Mat., vol. 3, no. 1, pp. 18-28, 2018.

[30] J. Lestari, O. H. Pranata, and D. A. M. L, "Desain Didaktis Jaring-Jaring Kubus dan Balok untuk Mengembangkan Kemampuan Berpikir Kreatif Siswa," PEDADIDAKTIKA J. Ilm. Pendidik. GURU Sekol. DASAR, vol. 5, no. 1, pp. 263273, 2018. 